\title{
GIPR Gene
}

National Cancer Institute

\section{Source}

National Cancer Institute. GIPR Gene. NCI Thesaurus. Code C24429.

This gene is involved in G protein-coupled receptor signal transduction and may play a role in glucocorticoid and anabolic metabolism. 